\title{
Regearch Article: Per se performance in tomato (Solanum lycopersicum L.) for yield attributes, yield and quality
}

口 V. RAMANA, D. SRIHARI, R.V.S.K. REDDY, M. SUJATHA AND M.H.V. BHAVE

Article Chronicle: Received :

10.07.2017;

Accepted :

25.07.2017

KEY Words:

Tomato, Per se, Diallele, Yield

Author for correspondence :

\section{RAMANA}

Horticulture Polytechnic

Madakasira,

ANANTHAPURAM (A.P.)

INDIA

Email : hortirams@

yahoo.co.in

See end of the article for authors' affiliations
SUMMARY : The present investigation "Studies on heterosis, combining ability and inbreeding depression in tomato (Solanum lycopersicum L)." for yield and quality was carried out during Rabi 2010-11, Kharif 2011 and Rabi,2011-2012 at Vegetable Research Station, Rajendranagar, Hyderabad to study the genetic parameters, heterosis, combining ability, gene action governing the inheritance of the traits, correlation co-efficient analysis, path co-efficient analysis and inbreeding depression. Ten parents (EC-165749, EC-157568, EC-164838, LE-56, LE-62, LE-64, LE-65, LE-66, LE-67 and LE-68) were crosssed in diallele mating design (without reciprocals). The resultant $45 \mathrm{~F}_{1}$ 's were evaluated along with their parents and two standard checks (Siri and US-618) for plant height $(\mathrm{cm})$, number of primary branches per plant, days to $50 \%$ flowering, number of fruits per cluster, fruit length $(\mathrm{cm})$, fruit width $(\mathrm{cm})$, average fruit weight $(\mathrm{g})$, fruit yield per plant $(\mathrm{kg})$, number of locules per fruit, pericarp thickness $(\mathrm{mm})$, TSS $\left({ }^{\circ}\right.$ Brix $)$, titrable acidity $(\%)$, ascorbic acid content $(\mathrm{mg} / 100 \mathrm{~g})$ and lycopene content ( $\mathrm{mg} 100 /$ g).

How to cite this article : Ramana, V., Srihari, D., Reddy, R.V.S.K., Sujatha, M. and Bhave, M.H.V. (2017). Per 12(TECHSEAR-3) : 718-724; DOI: 10.15740/HAS/AU/12.TECHSEAR(3)2017/718-724. se performance in tomato (Solanum lycopersicum L.) for yield attributes, yield and quality. Agric. Update, 